Kredo 4 (2020)
KREDO: Jurnal Ilmiah Bahasa dan Sastra
Terakreditasi Sinta 4 berdasarkan Keputusan Direktorat
Jenderal Penguatan Riset dan Pengembangan,
Kementerian Riset, Teknologi dan Pendidikan Tinggi
Republik Indonesia
Nomor: 23/E/KPT/2019. 08 Agustus 2019
https://jurnal.umk.ac.id/index.php/kredo/index

\title{
ANALISIS GAYA BAHASA DALAM PUISI ADA TILGRAM TIBA SENJA KARYA W.S. RENDRA: KAJIAN STILISTIKA
}

\author{
Mochammad Faizun \\ faizun@iain-tulungagung.ac.id
}

IAIN Tulungagung, Indonesia

Info Artikel
Sejarah Artikel
Diterima
21 Maret 2020
Disetujui
26 September 2020
Dipublikasikan
28 Oktober 2020

Keywords Ada Tilgram Tiba Senja, literary stylistics, poetry.

Kata Kunci Ada Tilgram Tiba Senja, puisi Stilistika sastra.

\begin{abstract}
: Abstract
This research is aim to understanding the language style in the poem Ada Tilgram Tiba Senja by W.S. Rendra. Literary language (especially in poetry) is very different from the daily coversations. The author has the authority to break the rules of language causing literary language to be different from conventional language. In order to understand the meaning of literary works properly and validly requires a stylistic study. This research uses a Roman Jakobson structurals approach with stylistic analysis. This study used a descriptive qualitative method, namely in-depth reading and the meaning of the poetry. The data analyzed were lines in poetry consisting of tones, words, phrases and sentences. The results of the study indicated that nasal sounds were used to image joy. The joyful atmosphere is also supported by several poetry poems with rhyme construction. From the lexical side, the selection of real words and figures of speech is used to : emphasize meaning. Rhetorical questions engage the reader in feeling the expressions in the poetry. Poetry verses form a series of stories starting from exposition, complication, climax, and resolution, with flashback and foreshadowing techniques. Between stanzas are strongly linked to become a complete unity of poetry meaning.
\end{abstract}

\begin{abstract}
Abstrak
Tujuan dari penelitian ini adalah untuk memahami gaya bahasa dalam puisi Ada Tilgram Tiba Senja karya W.S. Rendra. Bahasa sastra, terlebih pada puisi, berbeda dengan bahasa sehari-hari yang digunakan dalam komunikasi. Hal tersebut disebabkan oleh wewenang sastrawan untuk keluar dari kaidah bahasa (licentia poetica), menjadikan bentuk bahasa sastra semakin berjarak dari bahasa konvensional. Sehingga untuk memahami makna karya sastra dengan baik dan valid membutuhkan kajian gaya bahasa. Penelitian ini menggunakan pendekatan struktural Roman Jakobson dengan analisis stilistika sastra. Metode penelitian yang digunakan adalah kualitatif deskriptif, yaitu dengan pembacaan mendalam dan penghayatan serta pemaknaan puisi tersebut. Data yang akan dianalisis adalah larik-larik dalam puisi yang terdiri dari bunyi, kata, frasa, dan kalimat. Hasil dari penelitian menunjukkan bahwa penggunaan bunyi sengau untuk mencitrakan kegembiraan. Suasana gembira juga didukung dengan beberapa sajak puisi dengan konstruksi pantun. Secara leksikal pemilihan kata nyata maupun majas didayakan untuk mempertegas makna. Pendayaan pertanyaan retoris melibatkan pembaca dalam merasakan ungkapan dalam puisi. Bait-bait puisi membentuk rangkaian cerita dimulai dari eksposisi, komplikasi, klimaks, dan resolusi, dengan teknik flashback dan foreshadowing. Keterkaitan antar bait sangat kuat menjadi satu kesatuan makna puisi yang utuh.
\end{abstract}

\section{PENDAHULUAN}

Penggunaan bahasa agar dapat menarik minat baca seseorang adalah dengan cara membubuhkan atau menampilkan gaya bahasa. Endraswara (2008: 71) menjelaskan bahwa gaya (style) adalah segala hal yang menyimpang dari pemakaian biasa yang ditujukan untuk memperoleh keindahan. Keindahan ini banyak dijumpai dalam karya sastra, karena sifatnya yang penuh dengan unsur estetik. Kehadiran unsur estetik dalam penggunaan bahasa adalah 


Kredo 4 (2020)
KREDO: Jurnal Ilmiah Bahasa dan Sastra
Terakreditasi Sinta 4 berdasarkan Keputusan Direktorat
Jenderal Penguatan Riset dan Pengembangan,
Kementerian Riset, Teknologi dan Pendidikan Tinggi
Republik Indonesia
Nomor: 23/E/KPT/2019. 08 Agustus 2019
https://jurnal.umk.ac.id/index.php/kredo/index

untuk memunculkan manipulasi bahasa, misalnya dapat diibaratkan dengan sebuah plastik dan kertas yang membungkus kado adalah sebagian besar untuk menunjang keindahan dari bentuk kado tersebut. Manipulasi tersebut dinamakan gaya bahasa.

Enkvist (dalam Junus, 1989: 4) menunjukkan enam cara memandang gaya, pertama, stile dilihat sebagai sesuatu yang membungkus pikiran, kedua, style sebagai pilihan antara berbagai ragam pernyataan yang dimungkinkan, ketiga, stile sebagai kumpulan ciri pribadi, keempat, stilesebagai penyimpangan dari norma, kelima, stile sebagai sekumpulan ciri kolektif, dan keenam, stile sebagai hubungan bahasa yang dinyatakan dalam teks.

Adapun tujuan penelitian ini adalah mengkaji gaya bahasa puisi "Ada Tilgram Tiba Senja" karya Ws. Rendra. Kajian dilakukan dengan menganalisis unsur-unsur stile yaitu mulai dari bunyi, kata, gramatika, pemajasan, penyiasatan struktur, dan citraan. Setelah unsur-unsur stile diketahui karakteristiknya, dilanjutkan dengan kajian tentang pendayagunaan unsur-unsur tersebut dalam membangun makna puisi.

Gaya bahasa sastra berbeda dengan bahasa yang digunakan sehari-hari sebagaimana sarana komunikasi. Hal tersebut didukung dengan kebebasan sastrawan untuk tidak mengikuti kaidah bahasa yang disebut dengan istilah licentia poetica. Dengan kebebasan untuk keluar dari kaidah bahasa, bahasa sastra memiliki karakter dan kekhususan yang tidak sama dengan lainnya.

Di saat yang bersamaan, karakteristik dan kekhususan bahasa sastra membuat jarak antara makna dan struktur bahasa karya sastra. Untuk memahami karya sastra secara utuh diperlukan kajian mengenai karakteristik bahasa tersebut. Dengan demikian penelitian tentang gaya bahasa menjadi penting untuk memahami makna yang terkandung dalam karya sasta.

Bidang kajian yang meneliti pada gaya bahasa disebut juga dengan stilistika sebagaimana yang dinyakan Nurgiantoro (2014: 75) stilistika adalah kajian terhadap wujud performasi kebahasaan, khususnya yang terdapat pada teks-teks sastra.

Dalam penelitian stilistika seharusnya mampu menyentuh pada tingkat makna gaya bahasa, yaitu makna denotasi dan makna konotasi (Muhammad, 1988: 17-33). Kedua makna tersebut saling menopang membangun gaya bahasa. Pemaknaan denotasi dan konotasi memperhatikan deskripsi mental dan fiskal bahasa. Deskripsi ini akan tampak melalui ketepatan dan kesesuaian kosa kata, hasil dari pemilihan kata.

Puisi Ada Tilgram Tiba Senja karya W.S. Rendra berisi 14 bait yang bercerita tentang seorang ibu saat menerima tilgram dari anaknya. Tilgram tersebut mengabarkan bahwa anak akan pulang dari perantauan di kota. Puisi Ada Tilgram Tiba Senja berbeda dengan puisi-puisi W.S. Rendra yang lain. Puisi tersebut terasa lebih ringan dibandingkan dengan puisi-puisi lain yang terasa berat, setidaknya dalam antologi Ballada Orang-orang Tercinta.

Penggunaan ritme dan rima yang kuat, yang berkelindan dalam perasaan kesedihan ibu hidup dalam kesendirian dan kebahagiaan yang diterimanya 


Kredo 4 (2020)
KREDO: Jurnal Ilmiah Bahasa dan Sastra
Terakreditasi Sinta 4 berdasarkan Keputusan Direktorat
Jenderal Penguatan Riset dan Pengembangan,
Kementerian Riset, Teknologi dan Pendidikan Tinggi
Republik Indonesia
Nomor: 23/E/KPT/2019. 08 Agustus 2019
https://jurnal.umk.ac.id/index.php/kredo/index

melalui tilgram tersebut sangat menarik untuk diteliti. Hal tersebut juga didukung dengan pola pantun yang digunakan dalam beberapa baitnya.

Penelitian stilistika sastra sudah dilakukan oleh beberapa peneliti, di antaranya Fransori (2017) yang meneliti dengan judul Analis Stilistika pada Puisi Kepada Peminta-minta Karya Chairil Anwar. Analisis puisi tersebut menggunakan dua metode puisi, yaitu struktur fisik puisi dan struktur batin puisi.

Penelitian berikutnya adalah penelitian yang dilakukan oleh Cahyadi, dkk (2014) dengan judul Kajian Struktural, Stilistika, Dan Etnopedagogi Dalam Kumpulan Puisi (Sajak) Periode Tahun 2000-An. Penelitian tersebut mengombinasikan penelitian strukturalisme, stilistika, dan etnopedagogi. Hasil penelitian menekankan usaha dalam mengaitkan antara hasil analisis stilistika dengan pemanfaatan sebagai sarana Pendidikan budaya, dari pada analisis stilistika itu sendiri.

Kajian stilistika berikutnya dilakukan oleh Yunata (2013) yang mengkaji Telaah Stilistika dalam Syaur Burung Pungguk, dalam Antologi Syair Simbolik dalam Sastra Lama Indonesia. Analisis dilakukan dengan menyisir data dari unsur-unsur stile. Hasil penelitian menyatakan puisi didominasi bentuk kiasan perbandingan.

Berbeda dengan penelitianpenelitian yang sudah ada, penelitian ini akan mengkaji gaya bahasa puisi dengan bertolak dari unsur-unsur stilistika, mulai dari bunyi hingga kalimat dalam keseluruhan tubuh puisi. Hal tersebut dipilih karena adanya pendayaan yang baik pada seluruh unsur-unsur gaya bahasa dalam puisi Ada Tilgram Tiba Senja yang ditangkap oleh peneliti.

Penelitian ini nantinya diharapkan dapat meningkatkan pengetahuan tentang sastra bagi masyarakat, sehingga dapat memberikan dampak positif bagi peningkatan minat membaca terhadap karya sastra. Dengan meningkatnya pengetahuan sastra dan minat baca karya sastra, akan berdampak pada meningkatnya apresiasi pembaca terhadap karya sastra secara umum, dan khususnya puisi Ada Tilgram Tiba Senja karya WS. Rendra.

Sebagaimana hasil penelitian Nurmayani dan Hilmiyatun (2018: 178) menemukan bahwa kemampuan mengapresiasi karya sastra dapat dipengaruhi oleh pengetahuan tentang sastra dan minat membaca karya sastra secara bersama-sama. Dengan demikian apabila kebermanfaatan penelitian ini dapat dicapai, maka dapat pula untuk menambah khasanah kajian terhadap kesusastraan Indonesia.

\section{KAJIAN TEORI}

\section{A. Stilistika}

Roman Jakobson (dalam Ratna, 2016: 47) mengemukaan enam fungsi bahasa, yaitu: emotive, refential, poetic, phatic, metalingual, dan conative. Menurutnya dari enam fungsi tersebut, fungsi puitik yang paling dominan. Puitika bertujuan menemukan karakteristik yang khas dari seni-bahasa.

Stilistika berasal dari kata style yang memiliki arti gaya. Menurut Ratna (2009: 3) Stilistika adalah ilmu tentang gaya, sedangkan style secara umum merupakan cara yang khas dalam 


Kredo 4(2020)
KREDO: Jurnal Ilmiah Bahasa dan Sastra
Terakreditasi Sinta 4 berdasarkan Keputusan Direktorat
Jenderal Penguatan Riset dan Pengembangan,
Kementerian Riset, Teknologi dan Pendidikan Tinggi
Republik Indonesia
Nomor: 23/E/KPT/2019. 08 Agustus 2019
https://jurnal.umk.ac.id/index.php/kredo/index

mengungkapkan sesuatu dengan cara tertentu. Kekhasan tersebut bertujuan supaya tujuan yang dimaksud dapat tercapai secara maksimal.

Dalam penelitian gaya bahasa terdapat tiga aspek yang diteliti. Pertama dari sisi penulis, yaitu mengkaji kedalaman penulis dalam menyusun gaya bahasa. Kedua, dari segi ciri teks sastra. Dan ketiga, gaya bahasa dalam membentuk kesan yang diperoleh pembaca. Aspek yang terakhir atau ketiga cenderung mengarah pada faktor resepsi sastra (Endraswara, 2008: 73).

Wellek dan Warren (1995: 226) menyebutkan dalam kajian stilistika terdapat dua pendekatan yang bisa dilalui. Pertama, diawali dengan analisis sistematis tentang sistem bahasa karya sastra kemudian dilanjutkan menginterpretasikan karakteristiknya dilihat dari segi estetis untuk mengungkapkan makna keseluruhan. Kedua, mempelajari tentang ciri-ciri yang membedakan sistem satu dengan sistem lainnya. Perbedaan tersebut dapat diketahui dengan membandingkan keduanya. Dapat dilakukan dengan memperhatikan deviasi-deviasi, misalnya pengulangan bunyi, inversi susunan kata, dan susunan hirerarki klausa. Kesemuanya itu memiliki fungsi estetis seperti membuat penekanan, membuat lebih jelas dan tajam atau kebalikannya yaitu fungsi mengaburkan dan membuat makna menjadi tidak jelas.

Adapun langkah-langkah analisis yang dapat dilakukan dalam penelitian stilistika adalah sebagai berikut (Endraswara, 2008: 75):

1. Menetapkan unit analisis, seperti bunyi atau nada, leksikal, frase, gramatika, bait, dan lain-lain.

70 | Jurnal Kredo Vol. 4 No. 1 Oktober 2020
2. Menganalisis hubungan pemakaian aliterasi, asonansi, ritme dan rima, serta variasi bunyi yang dimanfaatkan untuk membangun efek estetika.

3. Menganalisis diksi yaitu mengkaji tentang pemilihan kata yang digunakan untuk membangun makna dan keindahan bahasa. Kata memiliki lapis-lapis makna yang jika dimanfaatkan akan memberikan efek tertentu kepada pembaca.

4. Analisis gramatika ditekankan pada variasi penggunaan kalimat dalam kondisi yang berbeda-beda yang melatarbelakanginya.

5. Analisis makna juga perlu diperhatikan dan mendapat tekanan tersendiri. Kajian makna meliputi majas, yaitu bahasa figurative yang memiliki beragam makna.

Dari paparan tersebut dapat ditarik kesimpulan bahwa penelitian stilistika seharusnya sampai pada dua hal yaitu makna dan fungsi. Kajian makna dicari dengan penafsiran untuk mengetahui keseluruhan makna karya sastra, sedangkan fungsi dicari dengan mengkaji pemanfaatan setiap unsur stile dalam membangun makna. Pemanfaatan unsur-unsur stile dalam sastra dibentuk secara sengaja maupun tidak sengaja untuk memunculkan efek komunikasi sastra.

\section{B. Unsur-Unsur Stile}

Wujud formal stile adalah bahasa. Artinya stile dapat muncul dari ungkapan kebahasaan. Bahasa merupakan sebuah sistem yang di dalamnya terdapat sejumlah sub sistem yang bersama secara sinergis membentuk bahasa. Bahasa di sini 


Kredo 4(2020)
KREDO: Jurnal Ilmiah Bahasa dan Sastra
Terakreditasi Sinta 4 berdasarkan Keputusan Direktorat
Jenderal Penguatan Riset dan Pengembangan,
Kementerian Riset, Teknologi dan Pendidikan Tinggi
Republik Indonesia
Nomor: 23/E/KPT/2019. 08 Agustus 2019
https://jurnal.umk.ac.id/index.php/kredo/index

adalah bahasa yang secara nyata digunakan sebagai sarana komunikasi. Maka seperti halnya bahasa, stile adalah sub sistem bahasa. Artinya, komponen stile adalah komponen bahasa (Nurgiyantoro, 2014: 148).

Dengan demikian untuk mengetahui stile dari sebuah karya sastra, analisis dilakukan melalui penelusuran unsurunsur stile yang terdapat dalam bahasa. Unsur tersebut adalah bunyi, leksikal, struktur morfologis dan sintaksis, bahasa figuratif, sarana retorika, citraan, koherensi dan kohesi.

1. Bunyi

Bunyi merupakan aspek utama dalam bahasa. Bahasa bersifat konvensional yaitu sesuai dengan kesepakatan masyarakat melalui bunyi. Bunyi tertentu memiliki makna tertentu. Ada beberapa yang perlu diperhatikan dalam analisis bunyi yaitu persajakan, irama, nada dan suasana.

\section{Leksikal}

Aspek leksikal merupakan satuan terkecil dalam struktur sintaksis dan wacana. Unsur leksikal yang dimaksudkan di sini adalah pemilihan kata atau diksi. Yaitu bagaimana pengarang memilih kata tertentu untuk membangun makna dan keindahan bahasa. Dalam puisi terdapat dua aspek kata yaitu aspek bunyi dan aspek bentuk. Aspek bunyi kaitannya dengan pendayaan bunyi, dan aspek bentuk berkaitan dengan bentuk struktur morfologis dan sintaksis yang ada dalam larik puisi.

Analisis stilistika terhadap kata dilakukan dengan menjelaskan dan menafsirkan peran dan fungsi setiap bentuk kata sebagai fokus kajian dalam membangun dan membangkitkan efek keindahan.

\section{Gramatikal}

Analisis gramatika dalam stilistika adalah analisis struktur sintaksis yang terdiri dari unsur frasa, klausa, dan kalimat. Struktur sintaksis adalah susunan kata menurut kaidah tertentu. Sebuah kata bisa saja memiliki makna referensial, akan tetapi makna secara pasti yang dikandungnya baru dapat ditentukan setelah berada dalam struktur kalimat atau wacana yang memuatnya.

\section{Kohesi}

Kohesi adalah salah satu aspek penting dalam membangun retorika teks. Kohesi merupakan hal penting kaitannya dengan wacana dan analisis wacana. Dalam sebuah wacana kalimat saling bertaut membentuk makna yang lebih besar lagi. Kohesi adalah hubungan pertautan antar bagian dalam struktur sintaksis atau struktur wacana untuk menyampaikan muatan makna.

5. Pemajasan

Majas adalah bahasa figuratif. Penggunaan majas merupakan penyimpangan kebahasaan, yaitu penyimpangan dalam hal makna. Majas sangat beragam dan bermacam-macam. Secara umum berupa majas perbandingan dan majas pertautan. Majas perbandingan terdiri dari beberapa macam, yaitu simile, metafora, personifikasi, dan alegori. Sedangkan majas pertautan diantaranya adalah metonimi dan sinekdoki.

6. Penyiasatan struktur

Penyiasan struktur disebut juga dengan figures of speech. Penyiasatan struktur juga bermacam-macam yang secara umum dibagi menjadi dua yaitu repetisi dan pengontrasan. Yang 


Kredo 4(2020)
KREDO: Jurnal Ilmiah Bahasa dan Sastra
Terakreditasi Sinta 4 berdasarkan Keputusan Direktorat
Jenderal Penguatan Riset dan Pengembangan,
Kementerian Riset, Teknologi dan Pendidikan Tinggi
Republik Indonesia
Nomor: 23/E/KPT/2019. 08 Agustus 2019
https://jurnal.umk.ac.id/index.php/kredo/index

termasuk dalam repetisi adalah pararelisme, anafora, polisindenton dan asindenton, dan reptisi itu sendiri. Dalam pengontrasan terdapat hiperbola, litotes, paradoks, ironi dan sarkasme.

7. Citraan

Dalam dunia kesastraan dikenal adanya istilah citra dan citraan yang keduanya merujuk pada adanya reproduksi mental. Citra adalah gambaran berbagai pengalaman sensoris yang dibangkitkan oleh kata-kata. Citraan erat kaitannya dengan kelima indra manusia. Dari kelima indra tersebut terdapat lima citraan yaitu citraan penglihatan, pendengaran, gerak, rabaan, dan penciuman.

\section{METODE PENELITIAN}

Penelitian puisi Ada Tilgram Tiba Senja ini adalah penelitian struktural dengan pendekatan stilistika (gaya bahasa). penelitian perpustakaan (library research) yaitu penelitian yang dilakukan di kamar kerja peneliti atau di ruang perpustakaan di mana peneliti memperoleh data dan inforamasi tentang obyek penelitiannya lewat buku-buku atau alat-alat audio visual lainya (Semi; 1990:8).

Adapun metode kerja pada penelitian ini menggunakan metode kualitatif deskriptif yaitu mengutamakan kedalaman penghayatan terhadap interaksi antar konsep yang dikaji secara empiris. Langkah-langkah yang dilakukan meliputi, (1) Mengumpulkan data sesuai dengan kajian yang dilakukan, (2) membaca serta memahami puisi secara intensif, (3) melakukan analisis terhadap seluruh bagian puisi dengan berpedoman pada unsur-unsur gaya bahasa, dan (4) mendeskripsikan hasil analisis.

\section{HASIL DAN PEMBAHASAN}

Berbeda dengan telaah stilistika yang dilakukan oleh Yunata (2013) yang melakukan pelacakan data dengan bertolak dari unsur-unsur stile, dalam kajian peneliti Kajian stilistika puisi Ada Tilgram Tiba Senja karya WS Rendra ini penyisiran data dengan bertolak dari larik-larik puisi.

Kajian stilistika dalam penelitian ini dilakukan dengan pembacaan dari bait ke bait kemudian diklasifikasikan sesuai dengan unsur-unsur stile yang meliputi bunyi, kata, gramatika, pemajasan, penyiasatan struktur, dan citraan. Setelah unsur-unsur stile ditemukan, analisis berlanjut pada analisis karakteristik dan kekhasan dari unsur-unsur tersebut dengan mempertimbangkan kemungkinan pendayaan dari setiap unsur untuk membangun makna serta mencapai keindahan.

\section{(1) \\ (Ada tilgram tiba senja dari pusar kota yang gila disemat di dada bunda)}

Kata senja pada bait pertama, dapat bermakna donotatif sekaligus konotatif. Bermakna denotatif ketika tilgram datang di sore hari, sedangkan sebagai makna konotatif apa bila senja menunjukkan waktu yang cukup lama. Hal tersebut dapat dihubungkan dengan baris ketiga, disemat di dada bunda. Disemat atau ditempel di dada bunda, menunjukkan betapa bunda merindukan kedatangan tilgram tersebut sehingga

\section{2 | Jurnal Kredo} Vol. 4 No. 1 Oktober 2020 


Kredo 4 (2020)
KREDO: Jurnal Ilmiah Bahasa dan Sastra
Terakreditasi Sinta 4 berdasarkan Keputusan Direktorat
Jenderal Penguatan Riset dan Pengembangan,
Kementerian Riset, Teknologi dan Pendidikan Tinggi
Republik Indonesia
Nomor: 23/E/KPT/2019. 08 Agustus 2019
https://jurnal.umk.ac.id/index.php/kredo/index

didekatkannya dengan letak hati. Senja dapat dimaknai sebagai jangka waktu yang cukup lama menunggu kabar dari tilgram yang tiba.

Pusar kota yang gila merupakan kalimat metafora, makna referensial dari kata pusar adalah cekungan di tengah dinding perut bekas tali pusar. Kata tersebut dimanfaatkan untuk mengungkapkan pusat atau tengah kota yang gila. Kata gila, menjadi sifat dari pusat kota juga sebagai metafora yang menunjukkan tata kehidupan yang individualis dan anti sosial. Dapat juga menunjukkan carut marut kehidupannya. Kedua metafora didayakan untuk mempertajam makna.

Pada bait pertama terdapat beberapa kata nyata yaitu tiba, senja, semat, dan dada. Kata-kata tersebut sekaligus secara serentak membentuk rima akhir berupa huruf vokal "a" menjadikan ringan diucapkan dan membawa kesan riang. Seperti pada yang bertulis miring di bawah.

(Ada tilgram tiba senja

Dari pusar kota yang gila

Disemat di dada bunda)

Sedangkan rima awal terdapat pada kata, Ada tilgram tiba senja.

\section{(2)}

(BUNDA, LETIHKU TANDAS KE TULANG

ANAKDA KEMBALI PULANG)

Bait kedua ini merupakan isi telegram yang ditulis dengan huruf kapital. Isi tilgram berbentuk kalimat langsung. Bentuk pengungkapan isi tilgram menjadi kuat dan menarik, karena baris pertama menggunakan subjek kata ganti aku, si anak, sedangkan pada baris kedua menggunakan subjek orang ketiga yaitu anakda. Penyebutan anakda untuk diri sendiri membangun sekat dan jarak antara penutur dan yang dituturkan. Hal ini menjadikan anakda sebagai titik tekan dari pada menggunakan kata ganti aku.

Dari bait pertama ke bait kedua terdapat perubahan narator atau pencerita. Jika pada bait pertama pencerita adalah orang ketiga, sedangkan dalam bait kedua pencerita adalah orang pertama "aku" si anak.

Kata letih, tandas dan tulang merupakan kata nyata. Tandas ke tulang merupakan metafora yang mengacu pada rasa lelah luar biasa. Kata tandas sekaligus membangun citraan gerak yang kuat. Kelelahan yang luar biasa tersebut membuat anak ingin pulang. Di sini menegaskan bahwa rumah merupakan tempat istirahat terbaik anak.

Pada baris pertama bait ke dua terdapat rima awal, yaitu pada yang tertulis miring "Bunda, letihku tandas ke tulang". Sedangkan rima akhir suara sengau "ang". Kata Anakda ditulis dengan tidak baku sebagai ganti dari kata baku Ananda. Suara dari kata anakda lebih terasa berat daripada Ananda. Ada kemungkinan pemilihan kata tidak baku tersebut dimaksudkan untuk membangun makna situasi yang sulit.

\section{(3)}

Kapuk randu! Kapuk randu!
Selembut tudung cendawan
kuncup-kuncup di hatiku
pada mengembang bemerkahan.

Pada bait ketiga narator beralih ke orang pertama, "aku" sang bunda. Bait ketiga ini menggunakan kontruksi pantun; dua baris pertama sebagai sampiran, dan dua baris terakhir sebagai 


Kredo 4 (2020)
KREDO: Jurnal Ilmiah Bahasa dan Sastra
Terakreditasi Sinta 4 berdasarkan Keputusan Direktorat
Jenderal Penguatan Riset dan Pengembangan,
Kementerian Riset, Teknologi dan Pendidikan Tinggi
Republik Indonesia
Nomor: 23/E/KPT/2019. 08 Agustus 2019
https://jurnal.umk.ac.id/index.php/kredo/index

isi serta berima u-an-u-an. Meskipun sebagai sampiran, pemilihan kata sangat diperhitungkan. Kapuk randu adalah isi bunga yang sangat ringan dan lembut, selembut tudung cendawan yang berarti tutup atas jamur yang apabila kita sentuh terasa sangat lembut. Pemilihan kata pada sampiran mencitrakan rabaan halus sekaligus ringan yang mengarah pada suasana riang.

Kuncup di hati yang bemerkahan merupakan kalimat metafora, sekaligus terdapat citraan gerak. Citraan gerak tersebut menyatakan sebuah peralihan dari perasaan biasa menuju riang gembira. Dengan kabar anak akan pulang dari pengembaraan, ibu menjadi bahagia. Dalam bait kedua kita juga mendapatkan dua repetisi, yaitu repetisi frasa "Kapuk Randu, kapuk Randu" dan repetisi kata "kuncup-kuncup". Sebagaimana fungsi repetisi pada sajak secara umum, repetisi di sini juga difungsikan sebagai pembangun nada.

Bait pertama dan kedua berada dalam tanda kurung, seakan berfungsi sebagai nebentext seperti dalam naskah teater. Nebentext adalah teks samping dalam naskah teater yang biasanya ditulis dalam kurung berfungsi sebagai petunjuk pementasan. Tanda kurung dalam dua bait puisi ini menjadi latar dari bait-bait berikutnya. Asumsi tersebut sesuai dengan latar belakang penulis puisi, W.S. Rendra sebagai aktifis teater ternama di Indonesia.

\section{(4)}

Dulu ketika pamit mengembara

kuberi ia kuda bapanya

berwarna sawo muda

cepat larinya

jauh perginya.

74 | Jurnal Kredo

Vol. 4 No. 1 Oktober 2020
Setelah ibu merasakan kebahagiaan pada bait ketiga, pada bait keempat tema beralih pada nostalgia masa lalu. Hal tersebut menjadi sesuatu yang lazim. Seseorang ketika merasakan kebahagiaan dari sebuah perjumpaan, ingatannya akan kembali pada saat-saat perpisahan yang menyedihkan.

Dalam bait keempat, ibu membayangkan masa lalu dengan teknik flashback, di mana saat-saat anaknya akan berangkat mengembara. Mengembara memiliki makna pergi ke mana-mana tanpa tujuan dan tempat tinggal tertentu. Jika dilihat dari konteks kalimat yang menyatakan datangnya tilgram dari kota, maka pengembaraan anak adalah pengaduan nasib ke kota sebagaimana yang lazim dilakukan orang-orang desa untuk memperoleh kesejahteraan hidup secara materi.

Hal tersebut dikuatkan dengan kata kuda sebagai transportasi, maka hal ini memiliki keterkaitan dari segi tempat dan waktu sebagai plot puisi. Dari sisi tempat dan waktu, puisi ini mengungkapkan anak desa atau pedalaman pada jaman dahulu di saat tilgram masih menjadi sarana komunikasi dan kuda sebagai alat transportasi.

Mengembara, kuda, lari, dan pergi adalah kata nyata. Sawo muda sebagai warna kuda merupakan modifikasi dari metafora usang (Dead Metaphors) Sawo matang. Dengan digantinya sawo matang menjadi sawo muda, metafora yang usang terasa segar kembali. Pengubahan kata matang menjadi muda juga berfungsi sebagai penyelaras rima akhir dalam satu bait. 


Kredo 4(2020)
KREDO: Jurnal Ilmiah Bahasa dan Sastra
Terakreditasi Sinta 4 berdasarkan Keputusan Direktorat
Jenderal Penguatan Riset dan Pengembangan,
Kementerian Riset, Teknologi dan Pendidikan Tinggi
Republik Indonesia
Nomor: 23/E/KPT/2019. 08 Agustus 2019
https://jurnal.umk.ac.id/index.php/kredo/index

Selain permainan metafora, dalam bait ini juga terdapat pengulangan susunan hireraki klausa sebab akibat diagramatik. Yaitu pada kalimat "Cepat larinyal Jauh perginya". Makna klausa ke dua sebagai akibat dari adanya klausa pertama. Hal tersebut membentuk makna, jika cepat larinya maka jauh perginya. Dari segi rima, pada bait ini terdapat rima akhir a, a, a, a, a.

\section{(5)}

Dulu masanya rontok asam jawa untuk apa kurontokkan airmata? cepat larinya jauh perginya.

Terdapat inversi kata pada kalimat "Dulu masanya rontok asam jawa". Inversi adalah pembalikan kata, yang seharusnya "Dulu masanya asam jawa rontok". Inversi tersebut berfungsi sebagai pengedepanan (foregrounding) pada kata rontok, artinya benar-benar rontok berjatuhan. Hal ini sebagai penegas makna pada baris berikutnya, "Untuk apa kurontokkan air mata".

Di sini permainan kata yang apik dapat dicapai. Seakan air mata kesedihan atas perginya anak cukup diwakili oleh berjatuhannya buah asam Jawa dari pohonnya sehingga ibu tidak perlu mengucurkan air mata. Repetisi atau pengulangan terjadi pada dua baris terakhir pada bait kelima dengan dua baris terakhir bait keempat. Terasa sebagai kerelaan yang berat dari melepas sesuatu yang sangat disayangi.

(6)

Lelaki yang kuat biarlah menuruti darahnya menghunjam ke rimba dan pusar kota

Bait keenam merupakan argumen ibu untuk melepas anaknya pergi. Katakata nyata kuat, darah, hujam, dan rimba membangun makna keperkasaan lakilaki. Sinekdoki dalam kalimat menuruti darah menegaskan sifat kelaki-lakian yang selalu mengikuti kata hati. Pemilihan kata hujam yang berarti menancap mencitrakan gerak kuat pada langkah lelaki.

Kata rimba adalah inti dari hutan, sedangkan pusar kota adalah inti dari kota. Rimba dan kota merupakan antonimi dengan oposisi relasional. Yaitu oposisi antar dua kata yang mengandung relasi kebalikan (Gorys Keraf, 1986: 40)

Rimba dan pusar kota menyatakan rangkuman dari semua jarak. Langkah lelaki yang kuat dapat mencapai titik puncak rasa sepi begitu puncak keramaian. Bait keenam mendayakan seluruh kata untuk mempertajam makna.

Sifat tabiat laki-laki tersebut digunakan ibu sebagai pelipur hatinya yang sedih ketika ditinggal mengembara anaknya. Dengan mengembalikan setiap sesuatu pada sifat asalnya, akan lebih mudah untuk merelakan dan mengikhlaskan rasa keterpisahan.

\section{(7)}

Tinggal bunda di rumah menepuki dada melepas hari tua, melepas doa-doa cepat larinya

jauh perginya.

Bait ke tujuh adalah deskripsi di saat ibu ditinggal pergi seorang anak. 


Kredo 4 (2020)
KREDO: Jurnal Ilmiah Bahasa dan Sastra
Terakreditasi Sinta 4 berdasarkan Keputusan Direktorat
Jenderal Penguatan Riset dan Pengembangan,
Kementerian Riset, Teknologi dan Pendidikan Tinggi
Republik Indonesia
Nomor: 23/E/KPT/2019. 08 Agustus 2019
https://jurnal.umk.ac.id/index.php/kredo/index

Penggunaan kata bunda untuk menyebut penutur pertama juga sebagai pementingan. Menepuki dada dapat dimaknai sebagai denotasi juga dapat sebagi majas. Sebagai majas yang berarti harus merelakan anaknya pergi. Yaitu pelipur lara dengan mengelus dada pusat rasa kehilangan itu berada.

Kepergian anak bagi ibu adalah sebuah dilema. Satu sisi ia ingin anaknya selalu berada dekat dengannya. Namun di sisi lain lelaki memiliki jiwa pengembara yang oleh ibu disamakan dengan langkah kuda, cepat larinya, jauh perginya, dengan memanfaatkan repetisi dari bait-bait sebelumnya.

Pada baris kedua terdapat pengulangan pola pada awal struktur sintaksis (anafora), yaitu pada kalimat melepas hari tua/melepas doa-doa. Melepas juga merupakan metafora yang membawa imaji pembaca bahwa benarbenar dihabiskannya usia di rumah dan selama itu bunda selalu berdoa untuk anaknya yang sedang mengembara.

Pemilihan kata melepas doa, membawa pesan religiusitas pada ibu. Sebagaimana ia melepas hari tua, sebagai sifat yang melekat dan harus dilalui oleh setiap manusia. Melepas doa juga berkorelasi dengan melepas sesuatu yang ada dalam diri ibu. Selain menegaskan sisi religi, pengharapan kepada Tuhan melalui doa adalah karakteristik masyarakat Jawa.

Sebagaimana temuan Setiawan (2018: 112) dalam penelitiannya tentang pandangan hidup wanita Jawa dalam novel Bekisar Merah, menyatakan bahwa Lasi tokoh utama dalam novel tersebut selalu percaya bahwa Tuhan pasti mendengar doa-doanya. Hal tersebut terjadi dikarenakan kesadaran dalam hubungannya dengan Tuhan, manusia atau masyarakat Jawa selalu eling (ingat), pracaya (percaya), mituhu (percaya kepada Tuhan).

Rima akhir "a" masih mewarnai pada bait ke tujuh. Begitu juga pengulangan klausa sebab akibat diagramatik pada dua baris terakhir seperti bait keempat dan kelima.

\section{(8)}

\section{Elang yang gugur tergeletak elang yang gugur terebah satu harapku pada anak ingat 'kan pulang 'pabila lelah.}

Meski lelaki memiliki jiwa pengembara dengan kecepatan langkah dan jangkauannya yang jauh, ibu dapat memahami bahwa anaknya tetaplah manusia yang memiliki batas. Satu hal yang dapat menghentikan pengembaraan yaitu lelah. Maka betapapun ibu merelakan kepergian anaknya, dalam hatinya tetap terdapat harapan untuk kepulangannya.

Sebagaimana bait ketiga, bait kedelapan ini menggunakan konstruksi pantun dengan sajak ak, ah, ak, ah. Meski dengan bentuk pantun, dua sampiran atas didayakan untuk menunjukkan makna ketidakberdayaan, dan hal itu koheren dengan kata lelah pada baris keempat. Dua baris sampiran menggunakan bentuk repitisi anafora, sekaligus sebagai metafora.

Tergeletak dan terebah juga membentuk citraan gerak yang membawa pembaca seakan merasakan keruntuhan dari keperkasaan itu. Setelah anak merasakan lelah, maka satu harapan ibu; adalah kembali pulang.

\section{6 | Jurnal Kredo \\ Vol. 4 No. 1 Oktober 2020}




Kredo 4 (2020)
KREDO: Jurnal Ilmiah Bahasa dan Sastra
Terakreditasi Sinta 4 berdasarkan Keputusan Direktorat
Jenderal Penguatan Riset dan Pengembangan,
Kementerian Riset, Teknologi dan Pendidikan Tinggi
Republik Indonesia
Nomor: 23/E/KPT/2019. 08 Agustus 2019
https://jurnal.umk.ac.id/index.php/kredo/index

Pemendekan kata terjadi pada kata 'kan yang berasal dari kata akan, dan 'pabila dari kata apabila. Hal ini dilakukan untuk menyelaraskan suku kata yang berimplikasi pada nada.

(9)

Kecilnya dulu meremasi susuku

kini letih pulang ke ibu

hatiku tersedu

hatiku tersedu.

Pada bait kesembilan ibu mendeskripsikan ikatan batin yang erat dengan anaknya. Bagaimana dulu anak selalu didekap di dada, minum dan meremasi susunya, maka ikatan batin mulai terjalin. Rima akhir " $u$ " membentuk rasa haru. Kata bunda yang secara konsisten digunakan pada baitbait sebelumnya, pada bait ini menggunakan kata ibu. Pemilihan kata ibu untuk menyesuaikan dengan rima akhir yang selaras antar baris.

Pada dua baris terakhir terdapat repetisi kalimat, sekaligus menjalin nada dengan dua baris sebelumnya. Hati ibu tersedu, kata tersedu sebenarnya lebih cocok dengan manusia yang mengeluarkan suara di saat menangis, dan dalam bait ini digunakan sebagai predikat dari subjek hati. Hati adalah inti dari manusia, dan ia sedang tersedu merupakan pemilihan kata yang kuat. Keindahan ungkapan tersebut termasuk ke dalam majas personifikasi.

\section{(10)}

Bunga randu! Bunga randu! anakku lanang kembali kupangku.

Bait kesepuluh menggunakan konstruksi pantun dengan modifikasi yaitu satu baris sampiran dan satu baris berikutnya isi. Meski demikian pemilihan frasa pada sampiran tetap didayakan untuk menguatkan makna isi. Bunga randu adalah kapas yang sangat ringan, ikut mendukung makna baris kedua yang berisi rasa riang gembira ibu karena anaknya akan kembali padanya. Bunga randu juga koheren dengan frasa pada bait ketiga, kapuk Randu. Ini sebagai bukti bahwa terjadi ikatan makna yang kuat antar bait.

Peletakkan kata ganti kepemilikan "ku" diajukan ke kata anak yang secara normal seharusnya diletakkan pada kata lanang, karena anak lanang adalah bentuk frasa. Hal ini menunjukkan bahwa rasa kepemilikan anaknya ingin ditonjolkan. Penggunaan kata lanang yang berasal dari bahasa Jawa merupakan campur kode, ini menunjukkan bahwa di saat menyebut lanang kesadaran ibu kembali ke pernikpernik detail kesukuan Jawa.

Kalimat kembali kupangku merupakan keindahan majas hiperbola. Dipangku dapat dilakukan dengan anak kecil. Di sini ungkapan dilebih-lebihkan karena ibu sangat mengharapkan kehadiran anak di sampingnya, sekaligus memiliki relevansi dengan konteks pada bait sebelumnya yaitu tentang masa lalu dimana pengembara masih di usia anakanak.
(11)
Darah, o, darah
ia pun lelah
dan mengerti artinya rumah

Pada bait kesebelas ini ibu menyebut anaknya dengan kata darah. Darah memiliki kaitan dengan metafora 


Kredo 4(2020)
KREDO: Jurnal Ilmiah Bahasa dan Sastra
Terakreditasi Sinta 4 berdasarkan Keputusan Direktorat
Jenderal Penguatan Riset dan Pengembangan,
Kementerian Riset, Teknologi dan Pendidikan Tinggi
Republik Indonesia
Nomor: 23/E/KPT/2019. 08 Agustus 2019
https://jurnal.umk.ac.id/index.php/kredo/index

usang darah daging. Dapat juga mengacu pada bagian dari seseorang. Di sini pemilihan kata darah menegaskan eratnya hubungan anak dengan ibu.

Bait ini kembali menegaskan pentingnya rumah sebagai tempat peristirahatan seperti makna pada bait kedua. Pengulangan kata darah dengan sisipan "o" membentuk nada seakan sedang menimang bayi.

Nada pada bait sebelas termasuk kakofoni, yaitu nada yang berat dan sulit diucapkan. Namun demikian jika dibaca tetap terasa berdendang karena pengaturan ritme yang baik dengan menggunakan kaki sajak jambe pada baris pertama dan kedua, serta kaki sajak anapes pada baris ketiga. Sebagaimana dijabarkan sebagai berikut;

Da-rah,/o, da-rah

Lunak-keras/lunak-keras

Ia-pun/le-lah

Lunak-keras/lunak

Dan mengerti-artinya-rumah

Lunak-lunak-keras

(12)

Rumah mungil berjendela dua serta bunga di bendulnya bukankah itu mesra?

Bait kedua belas mendiskripsikan rumah yang akan dijadikan sebagai tempat kepulangan dari sang anak. Rumah kecil dengan dua jendela dan sedikit bunga di bendulnya. Bendul adalah ambang pintu. Di sini ibu mencoba menjelaskan bahwa kesederhanaan dapat menjadi sebuah kebahagiaan ketika dilalui dengan kebersamaan.

Kata mungil mengandung citraan visual yang kuat. Mencitrakan rumah yang benar-benar kecil dengan berjendela dua. Di sini semua kata didayakan untuk menggambarkan kesederhanaan. Meski rumah kecil namun tetap berhias bunga di bendulnya, sehingga membawa kesan tetap mencoba menjadi indah di dalam keterbatasan.

Di akhir baris terdapat kalimat, "Bukankah itu mesra?", bukan berarti harus dijawab. Pertanyaan tersebut sebagai bentuk penyiasatan struktur berupa pertanyaan retoris. Pertanyaan di sini berusaha melibatkan dan mengajak pembaca secara rasional dan emosional untuk merasakan kebahagiaan yang diraih dengan keterbatasan dan kesederhanaan.

\section{(13)}

Ada Podang pulang ke sarang tembangnya panjang berulangulang -pulang ya pulang, hai petualang!

Susunan pantun digunakan lagi pada bait ketiga belas. Dua baris atas sebagai sampiran dan isi yang semestinya dua baris, akan tetapi diringkas menjadi satu baris dengan rima akhir ang, ang, ang, ang. Begitu juga pada bait-bait sebelumnya yang menggunakan konstruksi pantun, dua sampiran tidak hanya difungsikan sebagai penyeimbang nada, akan tetapi juga didayakan untuk menegaskan makna baris isi.

Pada bait ini dua baris atas sebagai metafora. Burung Podang yang pulang ke sarang dengan tembang yang berulang seperti anaknya yang akan pulang ke rumah dengan riang. Pemilihan kata tembang untuk kicau burung merupakan keindahan

\section{8 | Jurnal Kredo \\ Vol. 4 No. 1 Oktober 2020}




Kredo 4(2020)
KREDO: Jurnal Ilmiah Bahasa dan Sastra
Terakreditasi Sinta 4 berdasarkan Keputusan Direktorat
Jenderal Penguatan Riset dan Pengembangan,
Kementerian Riset, Teknologi dan Pendidikan Tinggi
Republik Indonesia
Nomor: 23/E/KPT/2019. 08 Agustus 2019
https://jurnal.umk.ac.id/index.php/kredo/index

personifikasi, sekaligus sebagai penyeimbang rima.

Tekanan bunyi-bunyi sengau "Ang" membentuk nada riang dan bahagia saat diucapkan. Repetisi juga digunakan pada baris terakhir sehingga membentuk nada dendang yang indah dan gembira.

\section{(14)}

Ketapang.

Ketapang yang

kembang

berumpun di dekat perigi tua anakku datang, anakku pulang kembali kucium, kembali kuriba.

Bait keempat belas, sekaligus sebagai bait pamungkas dari puisi ini menggunakan struktur pantun dengan sajak ang-a-ang-a. Dua baris sampiran dan dua baris berikutnya sebagai isi.

Repetisi masih didayakan juga sebagai pembangun irama. Seperti, Ketapang. Ketapang yang kembang juga Anakku datang/ anakku pulang, serta kembali kucium/ kembali kuriba. Repetisi susunan kalimat membentuk irama nada berdendang.

Selain repetisi juga terbentuk paralelisme semantik. Di mana kalimat anakku datang dan anakku pulang, selajur dengan kalimat kembali kucium, kembali kuriba. Pemilihan kata kuriba daripada kupangku untuk menyesuaikan rima akhir sesuai dengan pola pantun.

Meskipun dua baris atas sebagai sampiran, pemilihan kata juga dipertimbangkan guna menjalin koherensi dengan isi pada dua baris setelahnya. Ketapang yang kembang bermakna kebahagiaan yang datang, dan berumpun (berkumpul) di dekat perigi (sumber mata air) tua, mengacu pada berkumpulnya keluarga di rumah asalnya.

Dari setiap bait secara semantik memiliki logika beruntut. Dimulai dari bait pertama datang sebuah tilgram, dan bait kedua tentang isi tilgram. Kedua bait ini sebagai deskripsi kronologi puisi, yaitu sebagai titik tolak bait-bait berikutnya.

Bait ketiga adalah respon ibu dari tilgram yang datang. Ibu merasakan kebahagiaan yang telah lama ditunggu kedatangannya.

Bait ketiga adalah akibat dari terjadinya bait pertama dan kedua. Dengan kabar kepulangan anak, maka hati ibu gembira saat itu juga. Bait pertama, kedua, dan ketiga juga sebagai eksposisi yaitu proses pengenalan informasi penting kepada pembaca.

Pada bait keempat mulai dibangun komplikasi, yaitu pembangunan konflik. Teknik yang digunakan adalah kilas balik. Dengan kepergian anak, mulai memunculkan konflik batin dalam hati ibu. Terlebih kepergian anak untuk mengembara yang tidak ada tujuan pasti di tempat yang asing yaitu kota.

Bait kelima berisi tentang usaha ibu untuk berdamai dengan kesedihannya ditinggal anak mengembara. Bait ke enam menyatakan usaha ibu untuk melepas ketegangan yang terjadi dengan mengembalikan segala sesuatu pada tabiatnya.

Pada bait ketujuh ibu mulai dapat berdamai dengan keadaan. Dengan terus melantunkan doa untuk anak, hati ibu dapat merasa tenang. Melepas doa sekaligus titik akhir dari kesedihan ibu, karena pada bait-bait setelahnya dimunculkan harapan dan kebahagiaan. 


Kredo 4 (2020)
KREDO: Jurnal Ilmiah Bahasa dan Sastra
Terakreditasi Sinta 4 berdasarkan Keputusan Direktorat
Jenderal Penguatan Riset dan Pengembangan,
Kementerian Riset, Teknologi dan Pendidikan Tinggi
Republik Indonesia
Nomor: 23/E/KPT/2019. 08 Agustus 2019
https://jurnal.umk.ac.id/index.php/kredo/index

\begin{tabular}{|c|c|c|}
\hline Bait & Isi & Alur \\
\hline 1 & Ada tilgram tiba & \multirow{3}{*}{ Eksposisi } \\
\hline 2 & Isi tilgram; anak akan pulang & \\
\hline 3 & Ibu merasa Bahagia & \\
\hline 4 & Saat kepergian anak & \multirow{4}{*}{$\begin{array}{l}\text { Komplikasi } \\
\text { (Flashback) }\end{array}$} \\
\hline 5 & Suasana batin ibu ditinggal anak & \\
\hline 6 & Ibu mereduksi kegelisahannya & \\
\hline 7 & Ibu berdamai dengan kesedihan & \\
\hline 8 & $\begin{array}{l}\text { Berharap kembali saat anak } \\
\text { lelah }\end{array}$ & Klimaks \\
\hline 9 & Menceritakan masa kecil anak & \multirow{6}{*}{$\begin{array}{c}\text { Resolusi } \\
\text { (Foresha- } \\
\text { dowing) }\end{array}$} \\
\hline 10 & Ibu bahagia anak akan pulang & \\
\hline 11 & Deskripsi pentingnya rumah & \\
\hline 12 & Deskripsi keindahan rumah & \\
\hline 13 & Bahagia anak akan pulang & \\
\hline 14 & Anak berada di sisi ibu & \\
\hline
\end{tabular}

Pada bait kedelapan, meski ibu sudah dapat berdamai dengan ketegangan-ketegangan atas rasa kehilangan, ia tetap berharap suatu saat anaknya pulang. Bait kedelapan ini juga sebagai klimaks dari komplikasi yang dibangun mulai pada bait ketiga.

Setelah lama menunggu akhirnya harapan itu datang juga sebagaimana makna pada bait kesembilan. Ibu terenyuh karena anak yang dulu selalu ditimang akan kembali pulang. Bait kesepuluh senada dengan bait kesembilan, berisi keriangan ibu dengan akan kembalinya anak ke sampingnya.

Pada bait kesebelas mengungkapkan pentingnya tanah kelahiran bagi para petualang. Dikuatkan dengan bait kedua belas yaitu meskipun bangunan kecil dan sederhana rumah adalah tempat terbaik bagi jiwa yang lelah. Bait ketiga belas merupakan ungkapan kebahagiaan ibu.

Puncak dari kebahagiaan seorang ibu dijelaskan dalam bait terakhir yaitu bait keempat belas. Dengan teknik foresha-dowing ibu mengungkapkan keberadaan anak di sisinya. Kembalinya anak merupakan kebahagian yang hakiki.

Bait kesepuluh sampai kelima belas sekaligus sebagai resolusi yaitu pemecahan masalah dari klimaks atas kesedihan ibu ditinggal anakknya mengembara. Pemecahan persoalan tersebut hanya dapat dilakukan dengan satu hal, anak kembali pulang di sisi ibunya.

Untuk lebih mudah dalam melihat alur tubuh puisi, dapat dijelaskan dalam tabel sebagai berikut:

\section{Tabel 1 Alur Puisi dalam Puisi Ada Tilgram} Senja

Dari alur logika makna puisi tersebut bisa kita ketahui bahwa puisi "Ada Tilgram Tiba senja" adalah sebuah cerita panjang, meskipun alur cerita diungkapkan dalam bentuk satu kesatuan kilas balik atau flashback dan harapanharapan di waktu yang akan datang atau Foreshadowing.

\section{SIMPULAN}

Dari kajian gaya bahasa di atas dapat disimpulkan:

1. Bunyi

Nada dalam puisi Ada Tilgram Tiba Senja didominasi dengan nada-nada ringan (eufony), meskipun ada sebagian kecil kalimat dengan nada berat (kakafoni). Pembetukan bunyi tidak terlepas dari pemilihan kata, repetisi, dan penggunaan konstruksi pantun. Terdapat juga beberapa pemendekan yang difungsikan untuk keselarasan rima. Bunyi-bunyi sengau banyak dimunculkan untuk membentuk rasa riang.

2. Leksikal

Dalam Ada Tilgram Tiba Senja terdapat kata nyata dan kata majas. Kata nyata maupun majas, semuanya dipilih 


Kredo 4(2020)
KREDO: Jurnal Ilmiah Bahasa dan Sastra
Terakreditasi Sinta 4 berdasarkan Keputusan Direktorat
Jenderal Penguatan Riset dan Pengembangan,
Kementerian Riset, Teknologi dan Pendidikan Tinggi
Republik Indonesia
Nomor: 23/E/KPT/2019. 08 Agustus 2019
https://jurnal.umk.ac.id/index.php/kredo/index

dengan tepat dan akurat, tidak satupun kata yang terlepas menguap begitu saja. Terdapat satu kata dari bahasa Jawa, dan itu merupakan campur kode. Pemilihan kata yang mengarah pada budaya daerah dimanfaatkan untuk menciptakan kesan perempuan desa yang bersuku Jawa.

3. Gramatika

Hampir seluruh baris dalam puisi berbentuk kalimat utuh. Ada beberapa susunan kalimat yang dibalik, dengan tujuan pengedepanan makna. Beberapa kalimat berbentuk repetisi, dan terdapat pengulangan susunan hireraki klausa sebab akibat diagramatik.

4. Kohesi

Keterkaitan antar bait puisi Ada Tilgram Tiba Senja sangat erat. Beberapa pengulangan juga mengaitkan dengan bait-bait yang lain. Sehingga untuk menemukan makna dalam satu bait, kita harus menelusuri konteksnya dengan memahami bait yang lainnya. Keterikatan ini dibangun oleh makna yang tidak utuh pada tiap baitnya, dan makna-makna tersebut dirangkai dalam konteks satu puisi secara utuh.

\section{Pemajasan}

Terdapat beberapa majas dalam puisi Ada Tilgram Tiba Senja, di antaranya metafora dan personifikasi. Pemilihan kata dalam majas didominasi oleh hewan dan tumbuhan. Hal ini sekaligus menegaskan bahwa penutur puisi tersebut adalah orang desa yang terdapat aneka flora dan fauna di sekitarnya. Kecermatan dalam pemilihan kata sebagai bahan pemajasan difungsikan untuk menguatkan dan menegaskan makna.

6. Citraan

Terdapat beberapa citraan dalam puisi Ada Tilgram Tiba Senja yaitu citraan audio, visual, citraan rabaan, maupun citraan gerak. Semua citraan dibangun dari pemilihan kata dan penyusunan kalimat yang akurat.

7. Penyiasatan struktur

Penyiasatan struktur dalam puisi Ada Tilgram Tiba Senja yang banyak ditemui adalah repetisi. Repetisi terjadi dalam kata, frasa, kalimat, dan antar bait. Repetisi yang beragam membangun wacana secara untuh dalam satu tubuh puisi. Repetisi-repetisi juga didayakan untuk membangun nada. Dari nada tersebut dapat memunculkan keindahan. Terdapat juga pertanyaan retoris yang berfungsi melibatkan pembaca secara rasional maupun emosional.

8. Gaya bahasa sebagai pembangun makna

Puisi Ada Tilgram Tiba Senja memanfaatkan seluruh unsur stilenya untuk membangun makna secara efektif. Mulai dari pemilihan kata, pengaturan ritme dan rima, pemanfaatan metafor, pertanyaan retoris, dan penggunaan struktur pola pantun pada beberapa baitnya.

Gaya bahasa puisi juga diupayakan untuk membangun karakter tokoh-tokoh yang ada di dalamnya. Terdapat dua tokoh yang diungkap secara eksplisit, yaitu ibu dan anak. 


Kredo 4 (2020)
KREDO: Jurnal Ilmiah Bahasa dan Sastra
Terakreditasi Sinta 4 berdasarkan Keputusan Direktorat
Jenderal Penguatan Riset dan Pengembangan,
Kementerian Riset, Teknologi dan Pendidikan Tinggi
Republik Indonesia
Nomor: 23/E/KPT/2019. 08 Agustus 2019
https://jurnal.umk.ac.id/index.php/kredo/index

\section{DAFTAR PUSTAKA}

Cahyadi, Acep Dery. 2014. “Kajian Struktural, Stilistika, dan Etnopedagogi dalam Kumpulan Puisi (Sajak) Periode Tahun 2000-An dalam Jurnal LOKABASA, Volume 5 Nomor 1 Tahun 2014.

Endraswara, Suwardi. 2008. Metodologi Penelitian Sastra. cet IV. Yogyakarta: Media Pressindo.

Fransori, Arinah. 2017. "Analisis Stilistika Pada Puisi Kepada Peminta-Minta Karya Chairil Anwar" dalam Jurnal Dieksis Volume 99 Nomor 1 tahun 2017.

Junus, Umar. 1989. Stilistik, Suatu Pengantar. Kuala Lumpur: Dewan Bahasa dan Pustaka, Kementrian Pendidikan Malaysia.

Keraf, Gorys. 1986. Diksi dan Gaya Bahasa. Cet III. Jakarta: Penerbit PT Gramedia.

Nurgiyantoro, Burhan. 2014. Stilistika. Yogyakarta: Gajah Mada University Press.

Nurmayani, Eva \& Hilmiyatun. 2018. "Hubungan Pengetahuan Tentang Sastra dan Minat Membaca Karya Sastra dengan Kemampuan Mengapresiasi Karya Sastra" dalam Jurnal Kredo Volume 2 Nomor 1 Tahun 2018.

Ratna, Nyoman Kutha. 2009. Stilistika. Yogyakarta: Pustaka Pelajar.

Rendra. WS. 1983. Ballada Orang-orang Tercinta. Cet V. Jakarta: Pustaka Jaya.

Rene Wellek \& Austin Warren (terjemahan). 1995. Teori Kesusastraan. Jakarta: PT Gramedia Pustaka Utama.

Semi, Atar. 1990. Metode penelitian Sastra, cet. 10. Bandung: ANGKASA.

Setiawan, Arif. 2018. "Pandangan Hidup Wanita Jawa Dalam Novel Bekisar Merah Karya Ahmad Tohari” dalam Jurnal Kredo Volume 1 Nomor 2 Tahun 2018.

Yunata, Elsa. 2013. "Telaah Stilistika dalam Syair Burung Pungguk" dalam Jurnal Bahasa Volume 8 Nomor 1Tahun 2013. 